\title{
У Hoidon alkuarvioinnin tulkintakehykset mielenterveystyössä
}

Mielenterveystyön hoidon alkuarvioinnissa selvitetään asiakkaan vahvuudet ja haasteet eri elämän osa-alueilla, punnitaan interventioiden tarve, hoidon tavoitteet ja hoidon seuranta. Mielenterveyshoidon alkuarvioinnin tulee olla suunnitelmallista ja laadukasta, jotta potilaan oikeus hyvään hoitoon toteutuu. Tässä tutkimuksessa tarkasteltiin, millaisissa tulkintakehyksissä (Goffman 1986) hoidon alkuarviointi jäsentyy mielenterveystyön moniammatillisen hoitotiimin ja asiakkaan välillä. Tutkimusaineistoina ovat videoidut ja litteroidut kolme hoidontarpeen arviointikäyntiä ja asiakastapaamisten jälkeen työntekijöiden käymät reflektiokeskustelut psykiatrisella polikilinikalla. Aineiston analyysin tuloksena alkuarvioinnista identifioitiin hoidontarpeen, mielenterveyden, huolen, ja tulevaisuuden tulkintakehykset. Tulosten perusteella asiakkaan ja työntekijöiden toiminta ja roolit vaihtelivat kehyksittäin. Hoidontarpeen arvioinnin ja mielenterveyden tulkintakehyksessä tavoitteina oli saada tietoa potilaan kokonaistilanteesta, oireista ja tehdä diagnoosi. Hoitotiimin jäsenet esittivät kysymyksiä, ja potilas oli selontekovelvollinen. Huolen tulkintakehyksessä tavoitteena oli lievittää potilaan diagnoosin aiheuttamaa stigmatisoitumista ja aktivoida potilasta rohkaisevilla, suostuttelevilla ja selitystä pyytävillä kysymyksillä. Potilaalla oli hoitoa tarvitsevan sairastuneen rooli. Tulevaisuuden tulkintakehyksessä tavoitteena oli potilaan toimijuuden tukeminen ja aktivointi sekä potilaan hoidon oikea-aikaisuuden turvaaminen. Potilaalla oli vastuullisen toimijan rooli. Tulokset tuovat näkyväksi hoidon alkuarvioinnin ja sen merkityksen omana työvaiheenaan mielenterveystyössä. Lisäksi tulokset auttavat tunnistamaan prosessin eri vaiheita, potilaan ja työntekijöiden rooleja ja kysymysten merkitystä. Tuloksia voidaan hyödyntää alkuarvioinnin kehittämisessä, sosiaali- ja terveydenhuollon ammattilaisten koulutuksessa ja käytännön potilastyössä.

\section{ASIASANAT: hoidon alkuarviointi, moniammatillisuus, mielenterveystyö, tulkintakehykset}

\section{AINI PEHKONEN, KAARINA MÖNKKÖNEN, TARU KEKONI}

\section{YDINASIAT}

- Hoidontarpeen alkuarvioinnin merkitys on olennainen hoito- ja palvelusuunnitelman laatimisessa.

- Alkuarviointia ei ole tutkittu omana systemaattisena työprosessina mielenterveystyössä.

- Tulokset osoittavat, että alkuarvioinnissa käytettiin hoidontarpeen, mielenterveyden, huolen ja tulevaisuuden tulkintakehyksiä.
- Potilaan ja työntekijöiden toiminta ja roolit vaihtelivat eri tulkintakehyksissä.

- Jatkossa alkuarviointia tulisi kehittää tietoisesti mielenterveystyön tärkeänä työvaiheena. 


\section{JOHDANTO}

\section{TUTKIMUKSEN LÄHTÖKOHDAT}

Terveyden- ja sosiaalihuollon organisaatioissa tehdään yhteistyötä sisäisiä ja ulkoisia hallinnollisia rajoja ylittäen. Organisaatioiden ulkoiset rajat ylittyvät verkostotyössä ja sisäiset hallinnolliset rajat silloin, kun yhteistyötä tehdään moniammatillisissa työryhmissä (1). Kun henkilö tulee palvelujärjestelmän asiakkaaksi, hän ylittää yksityisyyden ja julkisen rajan (2). Mielenterveyspalveluihin hakeutuminen ja siellä tehtävä moniammatillinen työ tarkoittavat useiden näkyvien ja näkymättömien rajojen ylittämistä. Työntekijöiden, ehkä toisistaan poikkeavat, professionaaliset ymmärrykset mielenterveysongelmasta, sen syistä ja hoitotavoista, kohtaavat potilaan odotukset. Potilaan kokonaistilannetta koskeva tieto rakentuu ja uutta tietoa rakennetaan vuorovaikutuksessa potilaan ja moniammatillisen työryhmän välillä sekä moniammatillisen työryhmän jäsenten välillä. Kriittisiä kysymyksiä potilastyössä ovat, halutaanko tietoa potilaasta, potilaalta vai potilaan kanssa, mikä on riittävää tietoa, keitä ovat tiedon tekijät, mikä on tiedon kohde ja käyttötarkoitus (3).

Moniammatillisuuteen liittyy paljon positiivista arvolatausta, kuten sujuvaa yhteistyötä, rajojen ylittämistä ja dynaamisuutta. Moniammatillinen työ mahdollistaa eri alojen työntekijöiden dialogisen keskustelun potilaan tilanteesta, jolloin potilaan kokonaistilanteen ymmärtäminen tapahtuu vuorovaikutuksessa. (4) Kun ammattien välisessä vuorovaikutuksessa syntyy jotakin uutta ja kunkin työryhmän jäsenen asiantuntijuus tulee hyödynnetyksi ryhmässä, voidaan puhua yhteisestä tiedonmuodostuksesta (5). Työntekijöiden taitoa tehdä moniammatillista työtä on määritelty moraaliseksi velvoitteeksi työskennellä yhdessä, jotta potilas saisi parhaan mahdollisen tuen (4).

Hoidontarpeen alkuarvioinnissa tuotettu tieto määrittää tulevia ratkaisuja, joten alkuarvioinnin merkitys potilaalle, hänen läheisille, ammatilliselle ja koko työprosessille on olennainen. Mielenterveyspotilaiden tarpeet ja voimavarat ilmenevät yksilöllisesti, joten niiden selvittämiseksi tarvitaan monipuolisia palveluja, keinoja ja toimintamalleja. Laajaa yhteiskunnallista ja ammatillista huolta ovat aiheuttaneet mielenterveyspalvelujen riittävyys, laatu, kustannukset ja hoidon oikea-aikaisuus erityisesti suhteessa palveluja tarvitsevien potilaiden kasvavaan määrään. (6)

Mielenterveystyö edellyttää useiden vastuullisten tahojen ja toimijoiden yhteistyötä sekä keskinäisen toiminnan yhteensovittamista. Lainsäädännöllä ja suosituksilla on haluttu turvata mielenterveyspalvelujen järjestäminen osaksi kansanterveystyötä (7-9). Potilaalla on oikeus saada hyvää hoitoa, kuntoutusta ja tietoa siitä, että palvelujen tarjoajalla on käytössään tieteellisesti tutkitut hoitomuodot ja käytännöt. Terveydenhuoltolain (10) 24 \$:n mukaisesti potilaan hoidon toteutukselle on tarvittaessa laadittava hoitoja palvelusuunnitelma, joka tulee laatia potilaan asemasta ja oikeuksista annetun lain (11) mukaisesti. Potilaan hoidon tarve ja palvelusuunnitelma laaditaan yhdessä potilaan itsensä, hänen omaistensa tai läheistensä tai laillisen edustajansa kanssa. Potilaiden on tarpeellista tietää ja ymmärtää, miten hoidon alkuarviointi toteutetaan ja mihin arviointi kohdistuu. Hoitosuunnitelma on siten osa potilasasiakirjaa.

Hoidontarpeen alkuarviointia on tutkimuskirjallisuudessa määritelty eri tavoin. Alkuarviointia on pidetty interventiona (12), asiakasprosessin alkuvaiheena (13), asiakkaan osallisuuden lisäämisenä (14), tiedon keräämisenä (15) ja tavoitteen määrittelynä (16). Eri erikoisalojen hoidon alkuarvioinnin menetelmät perustuvat kullekin alalle ominaiseen tiedonmuodostukseen ja ammatillisten käytäntöjen kehittämistyöhön. Lastensuojelun alkuarvioinnin tutkimuksissa on selvitetty arvioinnin painopisteitä, työmenetelmiä, yleistä orientaatiota ja alkuarvioinnin vaikutusta vanhempien näkökulmasta (17-23). Psykiatrisen hoidon suunnittelu- ja arviointitutkimukset ovat kohdistuneet potilaiden palvelutarpeen arvioinnissa käytettyyn RAI -järjestelmään (24-26) sekä TUVA -, FIM - ja GAS -mittaristoihin (27-29), psykogeriatrisen hoidon piirissä olevien ikääntyneiden avuntarpeen arvioinnin ASTA -arviointimenetelmään (30-31), mielenterveyskuntoutujan kuntoutussuunnitelman rakenteen kehittämiseen (32), mielenterveyskuntoutujien asumispalvelutarpeen arviointiin (33) ja kliinisiin käytäntöihin musiikkiterapian alkuarvioinnissa (34). Saaduissa tutkimustuloksissa ei ole muodostunut yksimielisyyttä siitä, mitä hoidon alkuarviointi on ja miten sitä tulisi toteuttaa tai miten hoidollisten ja kuntouttavien toimien 
seurantaa ja niitä arvioivaa tutkimusta tulisi tehdä (35-43).

Mielenterveystyössä hoidon palvelutarpeen arviointi on monitahoinen tiedonhankinnan prosessi. Tietoa kerätään potilaan vahvuuksista ja haasteista eri elämän osa-alueilla (esim. kognitiivinen, sosiaalinen ja motorinen), saatua tietoa käsitellään ja edelleen analysoidaan, tehdään diagnostinen tarkennus, pohditaan mahdollisesti aikaisempien arviointien pitävyys suhteessa nykyiseen tilanteeseen, punnitaan interventioiden tarve sekä hoidon tavoitteet, päämäärät ja hoidon seuranta. Hoidon palvelutarpeen arviointiin kuuluu useita tapaamisia, asiakaslähtöisyyttä ja vuorovaikutusta, jotta käsitys potilaasta ja hänen tilanteestaan muodostuisi. Alkuarvioinnin toteuttaminen edellyttää ammattilaisten jatkuvaa itsearviointia, tieteellisen tiedon hyödyntämistä ja myös muun tiedon hankintaa. Arviointiprosessi sisältää siis useita peräkkäisiä ja keskenään limittäisiä osaprosesseja.

Alkuarvioinnilla tarkoitetaan tässä tutkimuksessa potilaan kokonaisvaltaista hoidontarpeen arviointia moniammatillisessa mielenterveystyössä. Alkuarvioinnin tavoitteena on selvittää potilaan tarpeet, voimavarat ja tavoitteet sekä lisätä potilaan ja työntekijöiden tietoa ja ymmärrystä tilanteesta. Alkuarviointi voi toimia jo itsessään interventiona ja voi näin käynnistää muutoksia potilaan elämässä (17). Vaikka hoidon alkuarviointi jäsentyy omana prosessinaan ja interventiona, kytkeytyy se tässä artikkelissa tiiviisti suunnitelmalliseen, potilaalle sisällöltään oikeaan ja vaikuttavaan mielenterveystyön prosessiin. Aiemmin ilmestyneissä tutkimuksissa alkuarviointia ei ole tutkittu omana prosessinaan mielenterveystyössä. Tutkimukset ovat kohdentuneet alkuarvioinnissa standardoitujen mittaristojen ja kuntoutussuunnitelmien rakenteiden arvioimiseen.

\section{TUTKIMUKSEN TARKOITUS, TAVOITE JA TEHTÄVÄ}

Tämän tutkimuksen tarkoitus on kuvata mielenterveyshoidon alkuarviointia psykiatrisella poliklinikalla. Tämä tutkimus ei ole arviointitutkimus vaan arvioinnin tutkimus. Tutkimustehtävänä on analysoida sitä, millaisiin tulkintakehyksiin hoidon alkuarviointi jäsentyy mielenterveystyön moniammatillisessa tiimissä. Tutkimustulokset lisäävät tietoa hoidon alkuarvioinnista osana suunnitelmallista mielenterveystyötä, moniamma- tillisen tiimin jäsenten ja potilaan välisestä dynamiikasta sekä rooleista. Tutkimustulosten avulla saadaan tietoa siitä, missä positiossa potilas ja moniammatillisen tiimin työntekijät ovat yhteen toimimisessa sekä siitä, mitä tavoitteita, perusteita ja jännitteitä tiedonkeruussa on. Tutkimustuloksia voidaan hyödyntää myös muissa kuin mielenterveystyön alkuarvioinnin kehittämisen konteksteissa. Erwing Goffmanin (1986) tulkintakehysanalyysi antaa metodologisen välineen hoidon alkuarvioinnissa syntyvien suhteiden ja roolien analysointiin. Tulkintakehysanalyysia on käytetty mediatutkimuksessa, kasvatus-, yhteiskunta- ja kauppatieteellisessä tutkimuksessa (4451), mutta mielenterveyshoidon palvelutarpeen alkuarvioinnista ei vastaavia tutkimuksia löydy.

\section{EMPIIRINEN AINEISTO JA ANALYYSIMENETELMÄ}

Tutkimusaineistona on yhden asiakkaan kolme hoidontarpeen arviointikäyntiä ( $3 \times 45$ min.) psykiatrisella polikilinikalla. Asiakkaan hoidontarve arvioitiin moniammatillisessa tiimissä, johon kuului lääkäri, psykiatrinen sairaanhoitaja ja sosiaalityöntekijä. Arviointikäynnit ja potilastapaamisten jälkeen työntekijöiden käymät reflektiokeskustelut (3x60 min.) videoitiin. Tämän artikkelin kirjoittajista kaksi ensimmäistä olivat läsnä työntekijöiden reflektiokeskusteluissa, jolloin katsottiin moniammatillisen tiimin kanssa videotallenteet. Tutkijoina meillä oli mahdollisuus tehdä kysymyksiä työntekijöille ja osallistua keskusteluun, joten reflektiokeskustelut ovat analyysiä syventävä ja luotettavuutta lisäävä aineisto. Nauhoitettua materiaalia kertyi yhteensä 5 h 25 min. Reflektiokeskustelut ja hoidontarpeen arviointikäynnit litteroitiin (52 sivua, riviväli 1,15).

Aineiston analysoinnissa sovellettiin Erving Goffmanin (1986) tulkintakehysanalyysia. Goffmanin (52) mukaan ihmisten arkipäivän vuorovaikutus jäsentyy erilasten kehysten, kehysten välisen dynamiikan ja kehysten vaihtelun mukaisesti. Goffmanilaisittain kyse on tilannemääritelmästä, jossa pyritään ymmärtämään, ”mitä tässä on oikein meneillään". Riippuu kustakin tulkintakehyksestä, millaiseksi yksilön roolit ja muiden samassa tilanteessa olevien roolit hahmottuvat. Keskeistä on, kuinka kehystämisen yhteydessä määritellään vuorovaikutuksessa olevien positiot, ominaisuudet, oikeudet ja velvollisuudet. Kehysanalyysissä on siis kyse merkitystulkinnasta, jossa yksittäinen saa merkityksensä osana kokonai- 
suutta ja kokonaisuus määrittyy osiensa mukaan kuten hermeneuttisessa ymmärtämisessä. Tulkintakehysanalyyttisessa tarkastelussa Goffman painottaa tilannetta tai ilmiötä koskevien tulkintojen monikerroksisuutta.

Aineiston analyysi jakautui neljään toisiinsa kietoutuneeseen osaan: videotallenteisiin ja litteroidun aineistoon tutustumiseen, litteroidun tekstin analyyttiseen lähilukuun, kehysten muodostamiseen ja tutkimustulosten luotettavuuden testaamiseen. Ensimmäisessä analyysivaiheessa videotallenteita katseltiin yksin ja tutkijaryhmänä useita kertoja. Toisessa analyysivaiheessa litteroitua tekstiä luettiin yksityiskohtaisemmin kokonaiskuvan saamiseksi. Videotallenteet ja litteroitu aineisto täydensivät toisiaan. Jos litteroidussa aineistossa oli epäselviä tai monitulkintaisia kohtia, kyseinen tilanne katsottiin videotallenteelta tai päinvastoin. Toisessa analyysivaiheessa tarkastelu kohdentui alkuarvioinnissa ammattilaisten ja asiakkaan välisiin suhteisiin ja positioihin, joista tulkintakehysanalyysissa ollaan kiinnostuneita. Suhteiden avaaminen ja osallistujien positioiden erittely antoivat vihjeen tilanteen monikerroksisuudesta ja hoitotiimin jäsenten suhteista asiakkaan huoliin, avuntarpeeseen, asiakkaaseen ja hoitotiimin muihin jäseniin. Positioiden ja suhteiden avaaminen auttoivat alkuarvioinnin tulkintakehysten nimeämisessä. Analyysissä hyödynnettiin Goffmannin (1986) määrittelemiä avainkysymyksiä, jotka olivat tässä kontekstissa asiakastapaamisen peruste, tavoite, toiminta, keskeiset toimijat ja asiakkaan roolit sekä niiden väliset suhteet tilanteessa.

Kolmannessa vaiheessa nimettiin aineistoa jäsentävät tulkintakehykset. Kriittinen lukutapa kohdentui siihen, millaisia toiminnan tavoitteita ja perusteluja kuhunkin kehykseen liittyi. Kehys on analyysin keskeinen käsite ja sen kohde. Alkuarvioinnin työnperusteet kirjattiin yhden käsitteen tai sanaparin muodostamiksi kokonaisuuksiksi kuten lähete, potilaan unihäiriöt, potilaan syömiseen liittyvät huolet ja hyvinvoinnin vajeet. Tavoite, peruste ja toiminta kuvaavat alkuarvioinnin tiedontuotantoa prosessina. Keskeiset toimijat ja asiakkaan asema kuvaavat puolestaan asiakkaan ja työntekijöiden jännitteistä suhdetta. Avainkysymykset ohjasivat analyysia ja auttoivat selvittämään, mistä kaikesta alkuarvioinnissa oli kyse. Analyysin tuloksina identifioituivat hoidon alkuarvioinnin tulkintakehykset mielenterveystyössä.

Analyysin neljännessä vaiheessa katsottiin vielä videotallenteet, ja litteraatiot ja aineiston analyysi luettiin vaihe vaiheelta tulosten luotettavuuden varmistamiseksi. Uusi lukukierros tarkensi sanavalintoja, muttei muuttanut tulkintaa. Tehdystä analyysistä keskusteltiin tutkimusryhmässä ja psykiatrian poliklinikan moniammatillisessa tiimissä. Näin haluttiin varmistaa analyysin laatu. Analyysin tuloksina on moniammatillista työtä jäsentävät sisällölliset kehykset, joissa tulee näkyväksi asiakkaan ja hoitotiimin jäsenten väliset suhteet ja roolit. Tulkintakehykset ovat tutkijoiden nimeämiä ja ne esitetään prosessina alkuarvioinnin etenemisen mukaisesti.

\section{TUTKIMUKSEN TULOKSET}

Aineistosta identifoitui neljä hoidon alkuarvioinnissa toteutuvaa tulkintakehystä, jotka nimettiin hoidontarpeen, mielenterveyden, huolen ja tulevaisuuden tulkintakehyksiksi (Taulukko 1). Kokonaisuutena näistä kehyksistä paljastuu hoidon alkuarvioinnin tulkintakehykset mielenterveystyössä. Eri kehyksissä alkuarvioinnin moniulotteisuus tulee näkyväksi ja tulkintakehykset kietoutuvat yhteen hoidon alkuarvioinniksi. Aineistositaatit ovat asiakastapaamisten jälkeisistä reflektiokeskusteluista. Näin varmistamme asiakkaan yksityisyyden suojaa.

\section{HOIDONTARPEEN TULKINTAKEHYS}

Hoidontarpeen tulkintakehyksessä alkuarviointityön lähtökohtana oli poliklinikalle saapunut lähete perusterveydenhuollosta, lähetteen käsitteleminen tiimissä ja asiakkaan tapaamisesta sopiminen. Asiakkaalta tämä edellytti aktiivisuutta asiassaan eli saapumista poliklinikalle sovittuna aikana. Tavoitteena ammatilliselle työskentelylle oli asiakkaan kokonaistilanteen arviointi ja määrittely "mistä kaikesta oli kysymys" sekä tavoitteellisuus alkuarvioinnin toteuttamiseksi. Interventiona tavoitteiden saavuttamisessa olivat asiakkaan ja moniammatillisen tiimin väliset keskustelut, asiakkaan kanssa tehdyt sopimukset ja sitoumukset sovituista tapaamisajoista poliklinikalla sekä hoitokokoukset, joissa tiimin jäsenet pohtivat tilannetta ilman asiakkaan läsnäoloa. Hoidontarpeen tulkintakehyksessä pyrkimyksenä oli turvata tapaamisaikojen oikea-aikaisuus, 
Taulukko 1 Hoidon alkuarvioinnin tulkintakehykset

\begin{tabular}{|c|c|c|c|c|}
\hline & $\begin{array}{l}\text { Hoidontarpeen } \\
\text { tulkintakehys }\end{array}$ & $\begin{array}{l}\text { Mielenterveyden } \\
\text { tulkintakehys }\end{array}$ & $\begin{array}{l}\text { Huolen } \\
\text { tulkintakehys }\end{array}$ & $\begin{array}{l}\text { Tulevaisuuden } \\
\text { tulkintakehys }\end{array}$ \\
\hline Peruste & $\begin{array}{l}\text { Lähete } \\
\text { Ajanvaraus } \\
\text { Potilas aktiivinen } \\
\text { asiassaan }\end{array}$ & $\begin{array}{l}\text { Unihäiriöt, mielialan } \\
\text { vaihtelut, syömishäiriö, } \\
\text { harhat }\end{array}$ & Avun tarve & $\begin{array}{l}\text { Arjessa pärjäävä } \\
\text { Hyvinvoiva aikuinen }\end{array}$ \\
\hline Tavoite & $\begin{array}{l}\text { Tilanteen arviointi ja } \\
\text { määrittely, tavoitteiden } \\
\text { asettaminen }\end{array}$ & $\begin{array}{l}\text { Sairauden nimeäminen, } \\
\text { diagnoosi }\end{array}$ & $\begin{array}{l}\text { Inhimillisen kärsimyk- } \\
\text { sen ja pelon lievittä- } \\
\text { minen }\end{array}$ & $\begin{array}{l}\text { Autonominen ja itsestä } \\
\text { huolehtiva aikuinen } \\
\text { Hoidon oikea- } \\
\text { aikaisuus }\end{array}$ \\
\hline Toiminta & $\begin{array}{l}\text { Moniammatillisen } \\
\text { hoitotiimin tapaamiset, } \\
\text { hoitokokoukset, } \\
\text { sopimusten tekeminen, } \\
\text { oikea-aikaisuus } \\
\text { suunnitelmassa }\end{array}$ & $\begin{array}{l}\text { Lääkehoito ja sen } \\
\text { seuranta }\end{array}$ & $\begin{array}{l}\text { Sairauden stigman } \\
\text { vastapuhe } \\
\text { Terapia } \\
\text { Ohjaus ja neuvonta } \\
\text { taloudellisissa asioissa }\end{array}$ & Vastuuttava \\
\hline $\begin{array}{l}\text { Keskeiset } \\
\text { toimijat }\end{array}$ & $\begin{array}{l}\text { Potilas/asiakas/ } \\
\text { kuntoutuja } \\
\text { Moniammatillinen } \\
\text { hoitotiimi } \\
\end{array}$ & Lääkäri(t) & $\begin{array}{l}\text { Potilas, terapeutti, } \\
\text { monialainen hoitotiimi, } \\
\text { läheiset, muut palvelut }\end{array}$ & $\begin{array}{l}\text { Potilas, läheiset, } \\
\text { ystävät, hoitotiimi } \\
\text { kokonaisuudessaan }\end{array}$ \\
\hline $\begin{array}{l}\text { Potilaan } \\
\text { rooli }\end{array}$ & $\begin{array}{l}\text { Selontekovelvollinen } \\
\text { Hoitoa haluava ja } \\
\text { sitoutuva }\end{array}$ & Hoidettava & $\begin{array}{l}\text { Syrjäytymisvaarassa } \\
\text { oleva, avun ja } \\
\text { tuen tarvitsija, } \\
\text { "sairastunut", } \\
\text { hoidontarpeessa oleva }\end{array}$ & Aktiivinen toimija \\
\hline
\end{tabular}

vakuuttua asiakkaan valmiudesta yhteistyöhön ja lisäksi avata keskusteluun poliklinikan mahdollistamat resurssit. Keskeisinä toimijoina olivat potilas ja hoitotiimi. Potilaan rooli oli antaa tietoa asioistaan ja vastata kysymyksiin. Hän oli selontekovelvollinen, koska hän oli viestittänyt avun tarvettaan sekä halun olla osallisena hoidontarpeen alkuarviointiprosessissa.

Hoidontarpeen alkuarvioinnissa ammattilaisten tekemiä kysymyksiä ja tiedonintressiä perusteltiin näin:

Lääkäri: ”Ainakin aluksi sitä vointia ja siitä onko muuttunut lähetetietoihin nähden ja vahvistettuna se, että onko itsetuhoinen tällä hetkellä, tarvitaanko jotakin tukea. Lääkitysasiat ja sairasloma-asiat ovat yleensä niitä ensimmäisiä ja sosiaalinen, talouskysymykset." Sairaanhoitaja/terapeutti: "Tämä on hyvä tähän, siinä mielessä se toinen aika mikä tulee, se tulee oikeastaan tarpeeseen, se että, syvennetään näitä tietoja mitä tässä on tullut esille plus että miten siihen asti on mennyt.”

\section{MIELENTERVEYDEN TULKINTAKEHYS}

Mielenterveyden tulkintakehyksessä tavoitteena oli tunnistaa ja määrittää potilaalle diagnoosi. Potilas kertoi kärsivänsä unihäiriöistä, mielialan vaihteluista, syömishäiriöstä ja harhoista. Kyseiset oireet rajoittivat potilaan toimintakykyä ja arkea. Mielenterveyden tulkintakehyksessä dilemman aiheutti se, että potilas yhtäältä odotti diagnoosia ja toisaalta pelkäsi sitä. Diagnoosi oli alkuarviointia jäsentävä tekijä. Lääkäri kysyi ja kuunteli potilaan kuvausta oireista ja voinnista. Interventiona oli sairausloma töistä, lääkehoidon määrääminen alustavan diagnoosin perusteella ja lääkehoidon vaikutusten seuranta. Reseptilääkkeiden valinta ja lääkeannostukset edellyttivät tehdyn diagnoosin toistuvaa arviointia. Keskeinen toimija oli lääkäri ja potilaan roolina oli olla hoidettava. Vaikka diagnosointi, lääkemääräykset ja sairausloman pituus olivat lääkärin vastuulla, mielenterveyden tulkintakehyksessä tiedon keräämiseen osallistuivat myös tiimin muut jäsenet. Moniammatillisessa hoitotiimissä työntekijät kohtasivat potilaan oman professionaalisen tieto- 
perustan pohjalta ja kunkin työntekijän asiantuntijuus oli mahdollista yhdistää keskusteluissa.

Mielenterveyden tulkintakehyksessä hoitotiimin jäsenten työnjakoa alkuarvioinnissa pohdittiin näin:

Sairaanhoitaja/terapeutti: "Minä ajattelen, että meidän ammattirooli on siellä taustalla nykyisin, meillä on yhteinen keskustelu, mutta tietenkin on lääkärinrooli siellä taustalla. Sinä kyselet myös, puutut semmoisiin asioihin mitkä lääkärille kuuluu... minulla taas sitä yksilöterapeuttitausta, minä mietin siltä kannalta myös niitä asioita, mutta ei me tuoda koko ajan niitä, vaan taustalla."

Lääkäri: "Kyllä minä oman lääkärin osuuden olen yrittänyt pitää mielessä. Siinä tosiaan on ehkä sekin asia, et minä tarkistan lääkkeet ja sairasloma-asiat ja sitten onhan diagnostiikkakin koko ajan. Mielessä raksuttaa, mihinhän nämä oireet vois sopia ja...”.

\section{HUOLEN TULKINTAKEHYS}

Huolen tulkintakehyksessä tavoitteena oli potilaan inhimillisen kärsimyksen, pelon ja huolen lievittäminen. Potilas viestitti hoidon tarvettaan ja samalla saadun diagnoosin stigmatisoivaa merkitystä. Kun diagnoosi muuttuu sairauden sijasta stigmaksi, on se yhteisöllinen tuotos. Diagnoosi aiheutti potilaalle aiemmasta eletystä elämästä poikkeavan, uudenlaisen suhteen itsen ja ympäristön välille. Diagnoosi tuotti potilaalle toiseutta. Yksilöterapia, sairauden stigman vastapuhe, ohjaus ja neuvonta taloudellisissa asioissa, toimivat ammattihenkilöstön interventioina huolen tulkintakehyksessä. Keskeisinä toimijoina olivat potilas, terapeutti, moniammatillinen hoitotiimi, läheiset ja kolmannen sektorin palvelut. Potilas oli yksi toimija, joka vaikutti muihin toimijoihin ja johon muut toimijat vaikuttivat. Potilaan roolina huolen tulkintakehyksessä oli hoitoa, apua ja tukea tarvitseva, sairastunut ja syrjäytymisvaarassa oleva henkilö. Moniammatillinen tiimi kohtasi potilaan myös muuna kuin psykiatrisen poliklinikan potilaana, johon interventioilla pyrittiin.

Diagnoosin antamisen vastuullisuus ja se, miten potilas suhtautui diagnoosiin, aiheutti huolta sekä hoitotiimille että potilaalle itselleen. Terapeutti koki tilanteen ambivalentiksi. Potilas oli kertonut oireiden olevan normaaleja, koska suvussa oli enemmän oirehtivia kuin hän. Samalla potilas kuitenkin oli viestittänyt hoidon tarvettaan. Tästä antaa viitteen alla oleva keskustelu.

Lääkäri: "Kun siitä diagnoosista hänen kanssaan puhuttiin, niin hän oli kotona ollut aivan raivoissaan ja se on hänelle ollut katastrofi, että tämmöisiä diagnooseja laitetaan, että... Kyllä se pitää meidän kuitenkin laittaa. Kyllä tietysti ymmärtääkin sen. Mitä hän diagnoosista ajattelee, se voi tänään tuntua hyvälle, huomenna päivällä se voi tuntua ihan mahdottomalle. Siitä saa terapeutti sitten hänen kanssaan työskennellä mukavasti tai keskustelunaihetta riittää... sanoi silleen, että, se (diagnoosi) sulkee niin kun ovia..."

Sairaanhoitaja/terapeutti: "Oireita selitetään (potilas) normaaliksi, mutta sitten toivotaan pitkäjänteistä hoitoa.”

\section{TULEVAISUUDEN TULKINTAKEHYS}

Tulevaisuuden tulkintakehyksessä tavoitteena oli potilaan mielen hyvinvoinnin vahvistaminen sekä itsestä huolehtiva aikuinen, jotta arjessa pärjääminen olisi mahdollista. Potilaalle diagnoosin aiheuttama "kasvojen menetys" pyrittiin keskusteluissa palauttamaan. Potilaalle ei haluttu antaa tai vahvistaa sairaan kasvoja. Keskeisinä toimijoina olivat potilas, läheiset, ystävät, hoitotiimi kokonaisuudessaan muutospuheen vahvistajana. Potilaan rooli tulevaisuuden tulkintakehyksessä oli itsestä vastuussa oleva, aktiivinen ja vapaita valintoja tekevä toimija. Toimijuutta tarvitaan kansalaisena olemisessa, oppimisessa, koulutuksessa ja työssä. Potilaan voimavarojen realistinen ja konkreettinen arviointi oli pohjana esitetylle jatkotyöskentelylle tai hoidon lopettamiselle. Hoitotiimissä pohdittiin annetun diagnoosin vaikutusta potilaan tulevaisuuteen. Lääkäri pohti, milloin diagnoosi olisi ajallisesti viisasta kirjoittaa potilaalle huomioiden hänen ikänsä.

Lääkäri: "Nuoruudessa se on hyvin .., ollaan varovaisia, jos esimerkiksi kaksisuuntainen varsinkin psykoosisairaudet niin tietysti ajattelee, et nuoret kehittyy niin voi muuttua normaaliksi nuoren elämä ja tapa suhtautua asioihin, että se ei ihan diagnoosin laittaminen ei ole järkevä tapa.. Sitä minä ajattelen, että äiti... hän tietää, että masennus on, että 90 prosenttisesti periaatteessa paranee, mutta tämän tyyppinen ei parane, et hänellä on 
huolta siitä, mikä se hänen tulevaisuutensa oikein on."

Opiskelu ja ammatinvalinta sekä diagnoosi olivat hoidon alkuarvioinnin tulevaisuuden tulkintakehyksessä jännitteisessä suhteessa toisiinsa. Kirjoitettu sairausloma, säännöllisen terapian aloittaminen sekä valvottu lääkehoito suunnitelmana koettiin pohdinnan jälkeen hyväksi linjaukseksi.

Sosiaalityöntekijä: "Voisihan se olla, että onkin työkykyinen, sitten se suunnitelma on ihan hyvä...”

\section{POHDINTA}

Tutkimuksessa analysoitiin hoidon alkuarviointia mielenterveystyössä. Tässä artikkelissa vastattiin kysymykseen, millaisissa tulkintakehyksissä hoidon alkuarviointi jäsentyy mielenterveystyön moniammatillisessa hoitotiimissä. Menetelmälle ominaiset avainkysymykset ohjasivat analyysia ja auttoivat tunnistamaan potilaan ja moniammatillisen tiimin suhdetta, rooleja sekä sitä, mikä oli eri kehyksissä keskeistä ja mihin niissä tapahtuva toiminta perustui eri toimijoilla. Analyysin tuloksina nimettiin hoidontarpeen, mielenterveyden, huolen ja tulevaisuuden tulkintakehykset. Tulkintakehykset ja niiden keskinäiset suhteet erottuivat aineistosta selkeästi. Vaikka tulkintakehykset voidaan kuvata yksittäisinä ja toisistaan erottuvina, Goffmanin (1986) ajattelun mukaisesti yksittäinen toimija voi kuitenkin liikkua joustavasti tulkintakehyksestä toiseen. Tulkintakehysten suhde toisiinsa on dynaaminen ja jännitteinen, koska yksittäinen toimija voi myös tulkita samaa tilannetta useista eri kehyksistä käyden alkuarviointia avoimesti tai mielessään hiljaa.

Tavoite ja peruste kehystämisen apukysymyksinä avasivat keskustelun hoidon alkuarvioinnin tavoitteellisuudesta. Tutkimustulokset osoittavat, että alkuarvioinnin tavoitteellisuus näkyi moniammatillisen tiimin jäsenten kysymysten esittämisenä potilaalle ja odotuksena, että potilas vastaa esitettyihin kysymyksiin. Asiakas oli selontekovelvollinen ja sosiaalinen järjestys perustui vuorovaikutusta jäsentävää sovinnollista tapaa (53). Miten tahansa kysyminen ei ole mahdollista, sillä kysyttäessä pyritään rakentamaan ja ylläpitämään potilaan luottamusta, vastaamaan potilaan odotuksiin ja ylläpitämään keskustelun juonen jatkuvuutta. Potilaan velvollisuus ja oikeus on hakea apua hankalaan elämäntilanteeseen ja sairastuneen rooliin päästyään pyrkiä takaisin yhteiskunnan täysivaltaiseksi jäseneksi.

Hoidontarpeen arvioinnin ja mielenterveyden tulkintakehyksessä tavoitteina oli ensisijaisesti saada tietoa potilaan kokonaistilanteesta, oireista ja tehdä lääketieteellinen diagnoosi. Kysymykset ja keskustelu siirtyvät vähitellen potilaan tilanteen yleiskuvauksesta yksityiskohtaisempaan tietoon, tarkentaviin kysymyksiin. Aiemmissa tutkimuksissa $(54,55)$ on todettu, että kulttuurisesti rakentuneet potilas-lääkäri vuorovaikutuksen odotukset kertovat siitä, millaisena potilaat ja lääkärit hahmottavat omat roolinsa ja kenellä on oikeus diagnostiseen tietämykseen. Kansallisissa ja kansainvälissä tutkimuksissa $(56,57)$ todetaan, että potilaat vastustavat lääkärin antamaa diagnoosia harvoin. Tilanteissa, joissa potilaat vastustivat avoimesti lääkärin antamaa diagnoosia, lääkärit tekivät lopulta päätöksen, mikä vahvistaa instituution vahvasta asemasta ja merkityksestä.

Huolen tulkintakehyksessä tavoitteena oli lievittää potilaan stigmatisoitumista annetun diagnoosin jälkeen. Tavoite perustui ajatukseen, että psyykkisesti haurasta yhteiskunnan jäsentä ei suljeta yhteiskunnan ulkopuolelle, vaan hänet pyritään pitämään mukana normaalistamisen kautta (58,59). Keskustelu mielenterveyspotilaan stigmatisoitumisesta ja syrjäytymisestä kiinnittyy laajaan yhteiskunnalliseen keskusteluun kulttuurista, arvoista ja riskeistä. Yhtäältä potilas odotti diagnoosia saadakseen selville, mistä kaikesta on kysymys, mutta toisaalta hän pelkäsi diagnoosin aiheuttamaa stigmaa yhteiskunnan jäsenenä. Sairaus ja sairastuminen ovat riskejä itsensä toteuttamiselle, sosiaalisille suhteille, työllistymiselle, toimeentulolle ja asumiselle. Huolen tulkintakehyksessä kiinnostava tulos on, että moniammatillinen tiimi lievitti potilaan stigmatisoitumista aktivoimalla häntä keskusteluun eritavoin esitettyjen kysymysten avulla. Kysymykset esitettiin a) rohkaisevina "mikä sai sinut hakemaan opiskelupaikkaa?", b) suostuttelevina "olisikohan viisasta miettiä tätä tarkemmin?" ja c) selitysten pyytämisenä "miksi ajattelet noin?". Tutkimuksissa on todettu, että jo kysytyt kysymykset saavat mahdollisesti aikaan jo muutoksia potilaan ajattelussa ja toiminnassa (60).

Siinä missä huolen tulkintakehyksessä tavoitteena oli asiakkaan stigmatisoitumisen ja syrjäy- 
tymisen ehkäiseminen, tulevaisuuden tulkintakehyksessä tuettiin selviytymistä. Ensisijaisena tavoitteena oli tukea potilaan arjessa pärjäämistä ja vahvistaa siten arjen hyvinvointia. Jos ammattilaiset näkevät potilaan liian varhain omasta tilanteestaan vastuullisena toimijana, hän voi kokea turvattomuutta ja jäävänsä yksin. Sairaudesta johtuva rajoittunut tai rajoitettu toimijuus voi olla pitkäaikaista tai hetkellistä (61-63), joten potilaan toimijuuden arvioiminen kyseisissä tilanteissa tuo auttamistyöhön haasteen. Toimijuuden vahvistamisella ammattilaiset pyrkivät vahvistamaan potilaan identiteettiä, subjektiksi kasvamista, sosiaalista osallisuutta ja valintojen tekemistä. Tulevaisuuden tulkintakehyksessä on keskeistä diagnosoidun asiakkaan kasvojen palauttaminen ja toimijuuden tukeminen potilaan rytmissä.

Tämän tutkimuksen mielenkiintoinen tulos on, että kauttaaltaan alkuarvioinnin kohtaamisissa noudatettiin haastatteluformaattia, jossa tapaamisen muodostivat kysymys-vastaus -ketju ja hoitotiimillä oli valta ja kontrolli kysyttäviin asioihin. Potilas oli tarkkailija omassa asiassaan ja vastasi asetettuihin kysymyksiin. Moniammatillinen työryhmä pyrki aktivoimaan potilasta keskusteluun rohkaisevilla, suostuttelevilla ja selitystä pyytävillä kysymyksillä. Hoidon alkuarviointi tuotti tietoa potilaan tilanteesta kokonaistilanteesta ja tukitoimien tarpeellisuudesta. Alkuarvioinnin lopputuloksena potilaalle tarjottiin mahdollisuus yksilöterapiaan ja ohjaukseen kyseisessä organisaatiossa. Potilas päätti aloittaa terapian.

\section{TUTKIMUKSEN LUOTETTAVUUS JA EETTISYYS}

Tämän tutkimuksen luotettavuutta arvioidaan ladullisen tutkimuksen arviointikriteereillä (64) ja eettisiä valintoja Tutkimuseettisen neuvottelukunnan periaatteiden näkökulmasta (65). Tutkimuksen aineisto on kerätty autenttisesta tilanteesta, mikä lisää aineiston laadun luotettavuutta. Moniammatillisen hoitotiimin työntekijät olivat kokeneita ja koulutettuja ammattilaisia. Lupa tutkimuksen toteuttamiseen haettiin kyseisen organisaation tutkimuseettiseltä toimikunnalta. Kaikilta alkuarviointiin osallistuvilta pyydettiin kirjallinen suostumus videoinnista ja aineiston tutkimuskäytöstä. Kaikki osallistujat antoivat kirjallisen henkilökohtaisen suostumuksen. Kriittisesti arvioiden videokameroiden läsnäolo ja tietoisuus osallisuudesta tutkimukseen on voinut vaikuttaa asiakkaan ja hoitotiimin jäsenten toimintaan. Toisaalta tutkimuksissa on todettu (66), että tutkittavien toiminta normalisoituu nauhoituksen ja tapaamisen kuluessa eikä asiakastapaamisten ajallisessa kestossa ole ollut eroja suhteessa videoituihin tapaamisiin.

Tämän tutkimuksen luotettavuuden kannalta keskeistä on aineiston analyysin luotettavuus. Aineiston analyysissä pyrittiin tarkkuuteen ja huolellisuuteen. Saatuja tutkimustuloksia koeteltiin kehittämispäivässä, joka järjestettiin yhteistyössä kyseisen organisaation kanssa. Tutkimukseen osallistunut moniammatillinen tiimi oli paikalla. Tuolloin tarkennettiin tulkintakehysanalyysissä sanavalintoja ja sitä, että tutkijat olivat ymmärtäneet käytetyt sanavalinnat samoin kuin kyseiset ammattilaiset. Tällä haluttiin vahvistaa tutkimustulosten luotettavuutta. Tutkimustulosten siirrettävyys toiseen kontekstiin on kuitenkin riippuvainen, miten samankaltaisesta toimintaympäristöstä on kyse.

Aineiston kokoa on perusteltua pohtia kriittisesti. Videotallenteet toimivat tässä tutkimuksessa tekstianalyysin tukena ja varmistavat omalta osaltaan sensitiivisen tutkimuksen luotettavuutta sekä autenttisuutta. Laadullinen tutkimus ei lähtökohtaisesti pyri yleistettävyyteen vaan ilmiön ymmärtämiseen ja analyysin hienovireisyyteen. Jos laadullinen aineisto on laaja, analyysin tarkkuus voi kärsiä, vaikka toisaalta laaja aineisto antaa mahdollisuuden testata analyysin pätevyyttä laajemmassa aineistossa (67). Tässä tutkimuksessa saadut tulokset ovat parhaimmillaan siirrettävissä mielenterveyshoidon alkuarvioinnin tutkimus -ja kehittämistyöhön sekä mahdollisesti toiseen kontekstiin. Goffmanin mukaan tulkintakehysanalyysin toteuttamisessa aineiston määrä tai laajuus ei ole sinällään ratkaiseva tekijä. Rajatunkin aineiston avulla kehyksiä on mahdollista tulkita, joten tulkintakehysanalyysin toteuttaminen tässä aineistossa on perusteltua.

Tutkimukseen osallistuvien itsemääräämisoikeuden periaate perustui vapaehtoisuuteen ja tietoisuuteen osallistumisesta. Aineiston säilyttämisessä ja käsittelyssä noudatettiin kaikilta osin hyvää tieteellistä tapaa. Tulokset raportoidaan siten, että osallistujien anonymiteetti suojattiin hyvän tieteellisen käytännön mukaisesti. Tutkimustulosten raportoinnissa kiinnitettiin huomiota siihen, ettei tutkimukseen osallistuneita 
vahingoitettaisi. Tätä periaatetta reflektoitiin koko prosessin ajan. Tulosten raportoinnissa päädyttiin eettisistä syistä siihen, ettei potilaan puhetta tuoda suorina tekstikatkelmina tekstiin. Tämä valinta voi horjuttaa tutkimustulosten luotettavuutta ja tehdä potilaasta "näkymättömän". Potilaan yksityisyyden suojan kunnioittaminen on oikeutettua ja perusteltua.

\section{PÄÄTELMÄT}

Tutkimus tuotti tietoa hoidon tarpeen alkuarvioinnista osana suunnitelmallista mielenterveystyötä. Alkuarvioinnin merkitys on potilaalle ja palveluorganisaatiolle kiistaton. Alkuarviointi sisältää useita tapaamisia ja saadun tiedon kriittistä arvioimista, joten laadukkaan alkuarvioinnin saavuttaminen edellyttää palvelujärjestelmän tehokkuusajattelusta luopumista. Tässä tutkimuksessa saadut tulokset vahvistavat esittämään yhteiskunnallisen ja ammatillisen kysymyksen, toteutuuko yleisesti potilaan oikeus yhdenmukaiseen ja tasa-arvoiseen kohteluun hoidon alkuarvioinnissa. Potilas tulisi kohdata yksilönä, osoittaa hänelle aitoa kiinnostusta, tunnistaa potilaan voimavaroja ja pyrkiä ymmärtämään hänen kokonaiselämäntilannettaan. Lisäksi potilaalle tulisi antaa avoimesti informaatiota alkuarvioinnin työskentelytavoista ja menetelmistä sekä mitä arvioidaan ja mitä tiedolla tehdään. Avoin työskentely mahdollistaa luottamuksen syntymisen potilaan ja moniammatillisen työryhmän välillä.

Tulkintakehysanalyysi osoitti, että moniammatillisessa työryhmässä potilaan hoidon alkuarviointi on jännitteinen ja systemaattinen työprosessi. Työryhmän jäsenillä on oman professionsa lähtökohdista eri intressi kysyä tietoja potilaalta kokonaistilanteen ymmärtämiseksi. Yhtäältä psyykkiset ja sosiaaliset arviointipro- sessit ovat läsnä samanaikaisesti tiedonintressiä, toisaalta niiden kautta myös potilasta autetaan käymään sisäistä dialogia omassa toimijuudessaan. Pohdinta siitä, millaiset kysymykset ja miten esitettynä auttaisivat jo hoidon alkuarvioinnissa asiakkaan tilannetta, on erittäin oleellista. Kaikilla hoidon alkuarviointiin osallistuvilla on vaikutusta potilaan hoidon suunnitteluin. Potilaan luottamus ja itsemääräämisoikeus voi horjua, jos potilaan ja moniammatillisen työryhmän edustajien näkemyksissä on ristiriitaisuutta siitä, mikä on tarpeellista ja riittävää hoitoa. Yhtäältä ammattilaiset voivat ohittaa potilaan tarpeet tai eivät kuule niitä, toisaalta potilas ei välttämättä aina halua ottaa tarjottua apua ja tukea vastaan.

Tutkimustulosten perusteella potilas oli vähemmän aktiivinen osapuoli omassa asiassaan hoidon alkuarvioinnissa tapahtuneessa vuorovaikutuksessa. Moniammatillisen työryhmän työntekijät esittivät eri tulkintakehyksistä enemmän kysymyksiä kuin potilas moniammatilliselle työryhmälle. Mielenterveyshoidon alkuarvioinnin kehittämisessä tulisi kiinnittää huomiota työmuotoihin, joilla saisi potilasta aktivoiduksi omassa asiassaan. Osallistujarooli rakentuu vuorovaikutuksessa ja niistä odotuksista, joita osallistujilla on.

\section{KIRJOITTAJIEN KONTRIBUUTIOT:}

Pehkonen osallistui tutkimusartikkelin suunnitteluun, aineiston keräämiseen, teki aineiston analysoinnin ja kirjoitti käsikirjoituksen. Mönkkönen vastasi aineistonhankintaprosessin suunnittelusta ja toteutuksesta osallistuen aineiston hankintaan ja käsikirjoituksen kriittiseen kommentointiin. Kekoni osallistui tutkimuksen suunnitteluun ja käsikirjoituksen kriittiseen kommentointiin.

\section{Pehkonen,A., Mönkkönen, K., Kekoni, T. The frames of initial assessment of mental health. Sosiaalilääketieteellinen aikakauslehti - Journal of Social Medicine 2019: 56: I02-I 13.}

We investigate Erwing Goffman's (1974) framework analysis for initial evaluation of mental health care. We question frameworks structuring initial assessment of care in a multidisciplinary team of offering mental health services. The study material consisted of a videotape of one client's three-treatment needs assessment $(3 \times 45 \mathrm{~min}$.) and post-consumer feedback reflection discussions $(3 \times 60 \mathrm{~min}$.$) at the psychiatric polyclinics.$
From empirical data analysis, we identified the need care, mental health, concern, and future frames. The timing and activity of the patient in the treatment of the need for treatment was emphasized in the interpretation framework for treatment needs. In the mental health framework, the patient waited for and simultaneously feared the diagnosis. The concerns frame highlighted the stigma related to diagnosis; client feedback alle- 
viated this. Future framework revealed a realistic and concrete evaluation of the client resources to the client so that the basics existed either for the onset of treatment / therapy or termination of treatment. The results help identify the constructive dynamics of professionals during initial care assessment, which is an interesting addition to the multiprofessional care team for conversation and initial care assessment. Kirjoita/liitä tähän englanninkielinen versio tiivistelmästäsi.

\section{LÄHTEET}

(1) Toivanen M, Janhonen M, Järvensivu A. ym. Rajoja rikkovaa työtä: kun tehdään yhteistyötä yli hallinnollisten rajojen. Hallinnon tutkimus 2014; 33: 271-278. http://elektra.helsinki.fi/ se/h/0359-6680/33/3/rajojari.pdf

(2) Bury M. Illiness Narratives: Fact or Fiction? Sociology of Health and Illiness 2001; 23:263285.

https://doi.org/10.1111/1467-9566.00252

(3) Ojaniemi P, Rantajärvi K-M. Alkuarvioinnista suunnitelmalliseen lastensuojelun sosiaalityöhön. Kirjassa: Laitinen M, Pohjola A. (toim.)

Asiakkuus sosiaalityössä. Helsinki: Gaudea-mus; 2010, 224.

(4) Mönkkönen K. Vuorovaikutus asiakastyössä. Asiakkaan kohtaaminen sosiaali- ja terveysalalla. Tallinna: Gaudeamus; 2018.

(5) Tsoukas H. A. Dialogical Approach to the Creation of New Knowledge in Organizations. Or-ganization Science 2009; 20:941-957. https://doi.org/10.1287/orsc.1090.0435

(6) Helen I, Hämäläinen P, Metteri A. Komplekseja ja katkoksia - psykiatrian hajaantuminen suomalaiseen sosiaalivaltioon. Kirjassa: Helen I. (toim.) Reformin pirstaleet. Mielenterveyspolitikkaa hyvinvointivaltion jälkeen. Tampere: Vastapaino; 2011, 11-69.

(7) Erikoissairaanhoitolaki 1062/1989. https://www.finlex.fi/fi/laki/ajantasa/

(8) Mielenterveyslaki 2009/1066. https://www. finlex.fi/fi/laki/ajantasa/

(9) Mielenterveyspalvelujen laatusuositus 2001. Helsinki: sosiaali- ja terveysministeriön oppaita 2001;9.

(10) Terveydenhuoltolaki 30.12.2010/1326. https://www.finlex.fi/fi/laki/ajantasa/

(11) Laki potilaan asemasta ja oikeuksista 17.8.1992/785 http://www.finlex.fi/fi/laki/ajantasa/

(12) Dominelli L. Social Work: Theory and Practice for a Changing Profession. Cambridge, Malden: Polity; 2004.

(13) Compton B. R., Galaway B., Cournoyer, B. Social work processes. Belmont: Thomson Brooks/Cole; 2005.
Keywords: initial evaluation of care, multidisciplinary, mental health work, interpretation frameworks

Saapunut 17.04.2018

Hyväksytty 22.10.2018

(14) Tregeagle S., Mason, J. Service user experience of participation in child welfare case management. Child and family Social Work 2008; 13: 391-401.

(15) Milner J., O'Bryne P. Assessment in Social Work. Basingstoke: Palgrave Macmillan; 2009.

(16) Holland S. Child and family assessment in social work practice. London: Sage; 2004.

(17) Hietamäki J. Lastensuojelun alkuarvioinnin vaikutukset vanhempien näkökulmasta. Jyväskylä Studies in education, psychology and social research. 529. Jyväskylän yliopisto; 2015.

(18) Schene P. The Emergence of Differential Response. Protecting Children 2005; 20: 4-7.

(19) Holland, S. The Assessment Relationship: Interactions between Social Workers and Parents in Child Protection Assesment. British Journal of Social Work 2000; 30: 149-163. https://doi.org/10.1093/bjsw/30.2.149

(20) Khoo E, Hyvönen U, Nygren L. Child Welfare or Child Protection: Uncovering Swedish and Canadian Orientations to Social Intervention in Child Maltreatment. Qualitative Social Work 2002; 1: 451-471. https://doi.org/10.1177/14733250260620865

(21) Oranen M. Tutkimusta ja tunnustelua Lastensuojelun alkuarvioinnin käytäntöjä, malleja ja kehittämissuuntia. Alkuarviointi ja avohuoltotyöryhmän loppuraportti. Lastensuojelun kehittämisohjelma; 2006.

(22) Heino T. Keitä ovat uudet lastensuojelun asiakkaat? Tutkimus lapsista ja perheistä tilastolu-kujen takana. Helsinki: Sosiaali- ja terveysalan tutkimus- ja kehittämiskeskus; 2007.

(23) Muukkonen T, Tulensalo H. Kohtaavaa lastensuojelua: Lapsikeskeisen lastensuojelun sosiaa-lityön tilannearvion käsikirja. Helsingin kaupungin sosiaaliviraston selvityksiä 1; 2004.

(24) Finne-Sorvari H, Björkgren M,Vähäkangas P, Noro A. (toim.) Kotihoidon asiakasrakenne ja hoidon laatu: Rai-järjestelmä vertailukehittämisessä. Helsinki: Stakes M223; 2006. 
(25) Vähäkangas P. Kuntoutumista edistävä hoitajan toiminta ja sen johtaminen pitkäaikaisessa laitoshoidossa; 2010.

(26) Hautamäki L. Movements of Moods: Interplay between science, clinical practice and patient in psychiatry. Helsingin yliopisto; 2016.

(27) Leinonen K. Psykiatrisen potilaan hoidon suunnittelun arviointi RAI -järjestelmän avulla. Oulun seudun ammattikorkeakoulu; 2013. Luettu 1.8.2018. http://urn.fi/URN:nbn:fi:amk-2013090514989

(28) Tammelin K, Tuominen H. Mielenterveykuntoutujien asumisen valmiuksien arviointi. Satakunnan ammattikorkeakoulu; 2018.

(29) Sukula S, Vainiemi K, Laukkala T. GAS Menetelmästä sovellukseen. Kelan tutkimusosasto. Helsinki; 2015. Luettu 1.8.2018. ISBN 978-951-669-996-0 (PDF)

(30) Lehtonen I. Psykogeratrisen hoidon piirissä olevien ikääntyneiden avuntarpeen arviointi ASTA -arviointimenetelmällä. Jyväskylän ammattikorkeakoulu; 2015.

(31) Lehtoranta H, Luoma M-L, Muurinen S. Ikäihmisten laitoshoidon laadun kehittämishanke: Loppuraportti. Stakes. Helsinki: Valopaino Oy; 2007.

(32) Haverinen N. Mielenterveyskuntoutujien kuntoutussuunnitelman rakenteen kehittäminen. Kaakkois-Suomen ammattikorkeakoulu; 2018.

(33) Hagren S. Mielenterveyskuntoutujien asumispalvelutarpeen arviointi Jämsän mielenterveys-palveluissa. Jyväskylän ammattikorkeakoulu; 2017.

(34) Ala-Ruona E. Alkuarviointi kliinisenä käytäntönä psyykkisesti oireilevien musiikkiterapias-sa. Strategioita, menetelmiä ja apukeinoja. Jyväskylän yliopisto;2007. Luettu 15.1.2018. ISBN 978-951-39-3638-9 (PDF)

(35) Gurman A. S, Messer S. B. Contemporary Issues in the Theory and Practice of Psychotherapy. Kirjassa Gurman A.S, Messer S.B (toim.) Essential Psychotherapies: Therory and Practice (2nd ed). New York: Guilford Press; 2003, 1-23.

(36) Hartikainen K, Aaltonen J. (toim.) Näyttöön perustuva psykoterapia. Psykoterapian opetusja tutkimusklinikka; Jyväskylän yliopisto; 2005.

(37) Rissanen P. Terapiaa vai kuntoutusta. Kirjassa Kallanranta T, Rissanen P, Vilkkumaa I. (toim.) Kuntoutus. Helsinki: Duodecim 2001, 541.

(38) Lahtela L. Toimintakyvyn arvioimisen strategioista. Kirjassa: Talo S. (toim.) Toimintakyky - viitekehyksestä arviointiin ja mittaamiseen. Turku: Kela, Sosiaali- ja terveysturvan katsauksia 49, 2001.

(39) Wampold B. E. The Great Psychotherapy Debate - Models, Methods, and Findings. New Jersey \& London: Lawrence Erlbaum Associates, Publishers; 2001.

(40) Norcross J. C. (toim.) Psychotherapy Relationships That Work - Therapist Contributions and Responsiveness to Patients. New York: Oxford University Press; 2002.
(41) Leiman M. Vaikuttavuustutkimuksen pulmallisuus psykoterapiassa. Lääketieteellinen Aikakauskirja Duodecim 2004; 22: 2645-2653.

(42) Lahti I. Onko evidence based medicine Prokrusteen vuode psykoanalyyttiselle psykoterapialle? Psykoterapia 2004; 3: 211-216.

(43) Wilson B. L. Assessment of adult psychiatric clients: The role of music therapy. Kirjassa Unkefer R, Thaut M. (toim.) Music therapy in the treatment of adults with mental disorders: Theoretical bases and clinical interventions (2nd ed), Saint Louis: MMB; 2002, 155-180.

(44) Catani J. Yritystapahtuma kontekstina ja kulttuurisena kokemuksena. Jyväskylän yliopisto: Studies in Humanities: 109; 2008.

(45) Dieckmann P, Gaba D, Rall M. Deepening the Theoretical Foundations of Patient Simulation as Social Practice. Simulation in Health Care 2007; 3: 183-193.

https: //doi:10.1097/SIH.0b013e3180f637f5

(46) Kalliomaa S. Sisäinen markkinointi johtamisena. Tapaustutkimus konepajateollisuuden projektiorganisaatiosta. Akateeminen väitöskirja. Jyväskylä studies in Business and Economics: $82 ; 2009$.

(47) Karvonen E. Tulkintakehys (frame) ja kehystäminen. Media \& Viestintä 2000; 23: 78- 84.

(48) MalinV. Johtajasta tohtoriksi - osaajasta oppijaksi? Organisaatiossa oppimisen monta todellisuutta goffmanilaisena kehysanalyysina. Jyväskylä: Studies in Business and Economics 112; 2012.

(49) Peräkylä A. Kuoleman monet kasvot: identiteettien tuottaminen kuolevan potilaan hoidossa. Tampere: Vastapaino; 1990.

(50) Puroila A-M. Kohtaamisia päiväkotiarjessa kehysanalyyttinen näkökulma varhaiskasvatukseen. Akateeminen väitöskirja. Oulun yliopisto; 2002.

(51) Väänänen-Fomin M, Pehkonen A. Vuoden 1936 alkoholistilain tulkintakehykset. Historialli-nen Aikakauskirja 115:33- 44; 2017.

http://elektra.helsinki.fi/se/h/0018-2362/115/1/ vuoden19.pdf

(52) Goffman E. Frame Analysis. An Essay on the Organization of Experience. Northeastern University Press; 1986.

(53) Nuolijärvi P. Keskusteluntutkimus. K. Mäkelä (toim.) Kvalitatiivisen aineiston analyysi ja tulkinta. Helsinki: Gaudeamus;1990, 114-141.

(54) Ruusuvuori J. Potilaan rooli - onko sitä? Duodecim 2013:129, 656-658.

(55) Heritage J. Conversation analysis: practices and methods. Kirjassa: Siverman D, (toim.) Qua-litative Sociology. London: Sage; 2010, 208-230.

(56) Ijäs-Kallio T, Ruusuvuori J, Peräkylä A. Patient resistance towards diagnosis in primary care: implications for concordance. Health 2010; 14 : 505-522.

https://doi.org/10.1177/1363459309360798 
(57) Stivers T. "Symptoms only" and "candidate diagnosis": presenting the problem in pediatric encounters. Health Communication 2002; 14: 299-338.

(58) Alhanen K. Käytännöt ja ajattelu Michael Foucault'n filosofiassa. Helsinki: Gaudea-mus. 2007.

(59) Moré, S, Blom B. Explaining Human Change - On Generative Mechanisms in Social Work Practice. Journal of Critical Realism 2003; 2 : 37-61. https://doi.org/10.1558/jocr.v2i1.37

(60) Ahearn L. M. Language and agency. Annual review of anthropology 2001; 30: 109-137. https://doi.org/10.1146/annurev. anthro.30.1.109

(61) Gordon T. Toimijuuden käsitteen dilemmoja. Kirjassa Meurman-Solin A, Pyysiäinen I. (toim.) Ihmistieteet tänään. Tampere: Gaudeamus; 2008, 114-130.

(62) Hitlin S, Elder G. H. Time, self, and the curiously abstract concept of agency. Sociological theory 2007; 25:170-191. https://doi.org/10.1111/j.14679558.2007.00303.x

(63) Giddens A. Modernity and Self-Identity: Self and Society in the Late Modern Age. Combridge: Polity; 1991.
(64) Eskola J, Suoranta J. Johdatus laadulliseen tutkimukseen. Tampere: Vastapaino; 2000.

(65) Tutkimuseettisen neuvottelukunnan periaatteet 2009.

(66) Frey L. R, Botan C. H, Kreps G. L. Investigating communication: an introduction to research methods. Boston: Allyn and Bacon; 2000.

(67) Baker S.E, Edwards E. How many qualitative interviews is enough? Expert voices and early career reflections on sampling and cases in qualitative research. Southampton: National Centre for Research Methods; 2012.

Aini Pehkonen

VTT, dosentti, professori (ma.)

Yhteiskuntatieteiden laitos

Itä-Suomen yliopisto

KAARINA MÖNKKÖNEN

YTT, dosentti, yliopistonlehtori

Yhteiskuntatieteiden laitos

Itä-Suomen yliopisto

TARU KeKoni

YTT, yliopistonlehtori

Yhteiskuntatieteiden laitos

Itä-Suomen yliopisto 